\title{
Tasquinimod (ABR-215050), a quinoline-3-carboxamide anti-angiogenic agent, modulates the expression of thrombospondin-1 in human prostate tumors
}

\author{
Anders Olsson*1, Anders Björk1, Johan Vallon-Christersson², John T Isaacs ${ }^{3}$ and Tomas Leanderson 1,4
}

\begin{abstract}
Background: The orally active quinoline-3-carboxamide tasquinimod [ABR-215050; CAS number 254964-60-8), which currently is in a phase II-clinical trial in patients against metastatic prostate cancer, exhibits anti-tumor activity via inhibition of tumor angiogenesis in human and rodent tumors. To further explore the mode of action of tasquinimod, in vitro and in vivo experiments with gene microarray analysis were performed using LNCaP prostate tumor cells. The array data were validated by real-time semiquantitative reversed transcriptase polymerase chain reaction (sqRT-PCR) and protein expression techniques.

Results: One of the most significant differentially expressed genes both in vitro and in vivo after exposure to tasquinimod, was thrombospondin-1 (TSP1). The up-regulation of TSP1 mRNA in LNCaP tumor cells both in vitro and in vivo correlated with an increased expression and extra cellular secretion of TSP1 protein. When nude mice bearing CWR-22RH human prostate tumors were treated with oral tasquinimod, there was a profound growth inhibition, associated with an up-regulation of TSP1 and a down- regulation of HIF-1 alpha protein, androgen receptor protein (AR) and glucose transporter-1 protein within the tumor tissue. Changes in TSP1 expression were paralleled by an antiangiogenic response, as documented by decreased or unchanged tumor tissue levels of VEGF (a HIF-1 alpha down stream target) in the tumors from tasquinimod treated mice.

Conclusions: We conclude that tasquinimod-induced up-regulation of TSP1 is part of a mechanism involving downregulation of HIF1a and VEGF, which in turn leads to reduced angiogenesis via inhibition of the "angiogenic switch", that could explain tasquinimods therapeutic potential.
\end{abstract}

\section{Background}

During the last decades, development of new cancer treatments that are capable of inhibiting tumor growth by inhibition of the blood supply has received great attention $[1,2]$. The quinoline compound tasquinimod [ABR215050; CAS number 254964-60-8; 4-hydroxy-5-methoxy-N,1-dimethyl-2-oxo-N-[(4-trifluoromethyl) phenyl]1,2-dihydroquinoline-3-carboxamide] has emerged as a candidate [3], by virtue of its pharmacological profile with anti-angiogenic and anti-tumor potency in experimental human prostate cancer models $[4,5]$. Thrombospondin-1 (TSP1) is a $450 \mathrm{kDa}$ glycoprotein initially found

* Correspondence: anders.olsson@activebiotech.com

1 Active Biotech AB, Box 724, 22007 Lund, Sweden

Full list of author information is available at the end of the article in platelets, but also synthesized and secreted by many normal and transformed cells. TSP1 has been shown to be a potent natural inhibitor of tumor progression and metastases via inhibition of angiogenesis and migration or by activation of TGF $\beta$ (for review see [6-8]). Several mechanisms have been proposed for the anti-angiogenic properties of TSP1. For example, its type 1 repeat peptides (TSRs) [9] bind to and induce CD36-receptor signaling in endothelial cells and consequently lead to induction of apoptosis in endothelial tissue [10,11]. TSP1-induced signaling via CD47 and CD36 receptors expressed in endothelial cells also results in suppression of NO-dependent vascular pathways [12,13], and TSP1 acts as an apoptosis independent inhibitor of cell cycle 
progression [8]. Also, TSP1 inhibits neovascularization by interfering with FGF- and/or VEGF-induced angiogenesis via binding to, and blockage of, its receptors on the endothelial cell [14]. Furthermore, TSP1 negatively regulates the tissue levels of pro-angiogenic inducers (i.e. VEGF and FGF) and thereby shunts the "angiogenic switch" into an anti-angiogenic state $[7,15]$. Tissue level expressions of TSP1 are repressed by androgens in normal and cancer prostate tissue [16,17], and are down-regulated by several oncogenes including c-fos, c-jun, and Ras [18]. However, tumor suppressors such as PTEN, p53 and angiotensin II, but also PI3-kinase, $\beta_{1 \mathrm{C}}$ integrin, histone deacetylase (HDAC) inhibitors, and anti-cancer agents like dexrazoxane, up-regulate TSP1 levels [18-23]. Moreover, TSP1 modulates the expression of interleukin IL- 6 and IL-10 by human monocytes [24], which both have impact on tumor vascularization. Lastly, TSP1 inhibits inflammation [25] and promotes the recruitment of M1-polarized macrophages (TAM:s) [26] that express high levels of iNOS (inducible NO synthetase) [27].

Many different approaches have been used to increase the systemic levels of TSP1 in order to inhibit angiogenesis and counteract cancer growth. Among these approaches are metronomic therapy (i.e. continuous low dose chemotherapy) [28], and systemic delivery of recombinant proteins [29] or synthetic peptides [13,30] with TSR sequences the most successful. In the present study we investigated the molecular changes that underlie the anti-tumor effects of tasquinimod in human prostate cancer cells (LNCaP). We observed elevated levels of TSP1 mRNA and protein expression in both cell cultures and tumor tissue after exposure to tasquinimod. Thus, we were able to identify a possible mechanism for the antitumor effect of tasquinimod, involving up-regulation of TSP1 and inhibition of the "angiogenic switch".

\section{Results}

\section{Tasquinimods effects on gene expression in LNCaP cells} analyzed with DNA microarray

Tasquinimod has been documented to have a robust and consistent anti-angiogenic activity in vitro at doses between $10-50 \mu \mathrm{M}$ and in vivo at $1-10 \mathrm{mg} / \mathrm{kg} /$ day resulting in a potent anti-tumor effect in rodent and human prostate cancer xenografts tested in the same dose ranges $[4,5]$. Generated microarray data based on four separate biological replicates showed a drug-induced effect of 50 $\mu \mathrm{M}$ tasquinimod on gene expression in $\mathrm{LNCaP}$ cells when cultured in vitro for $24 \mathrm{~h}$. Up- and down-regulation (FDR $<0.1$; z-test) was noted for 107 genes (Additional file 1, Table S1). An in vivo experiment with LNCaP tumors inoculated (s.c.) into nude mice was also performed. Tumor bearing mice $(\mathrm{n}=2)$ were exposed to ABR-215050 at $10 \mathrm{mg} / \mathrm{kg}$ for $24 \mathrm{~h}$ at day 14 and day 21 after inoculation before the tumors were excised. There was a similar gene expression pattern between the two 24 $\mathrm{h}$ time points, and for this reason day 14 and day 21 data were pooled ( $\mathrm{n} \leq 4$, Additional file 2, Table S2). Table 1 lists a selected number of significantly up- or down-regulated genes after $24 \mathrm{~h}$ exposure to ABR-215050 (in vivo and/or in vitro). The presented genes were derived from significant clusters generated by a functional cluster analysis performed in the "DAVID and EASE" data base $[31,32]$. Briefly, the cluster analysis and pathway mapping revealed that many differentially expressed genes were involved in angiogenesis, cell cycle and apoptosis, migration, metabolism, signalling, DNA damage and oxidative stress (Table 1). Five of these genes, thrombospondin-1 (THBS1; TSP1), chemokine receptor CXCR4, cytochrome P450 1A1 (CYP1A1), receptor for advanced glycosylation endproduct (AGER; RAGE), and growth differentiation factor 15 (GDF15), were chosen for further validation using real time semi-quantitative RT-PCR. The expression data achieved by RT-PCR (Fig. 1B) were consistent with the microarray analysis data with a significant up-regulation of THBS1, GDF15 and CYP1A1 whereas $C X C R 4$ and $A G E R 1$ did not change expression significantly (Fig. $1 \mathrm{~B}$ and Table 1). Thus, the data achieved by microarray analysis after exposure to tasquinimod demonstrated a good agreement with semiqRT-PCR as an independent validation method.

\section{TSP1 mRNA and protein induction by tasquinimod in vitro cell cultures of tumor cells}

Among the most significant gene differentially expressed both in cell cultures and in tumor tissue after exposure to tasquinimod, was TSP1 (THBS1; indicated by arrow in Fig. 1A). The up-regulation of TSP1 mRNA levels in LNCaP cells after exposure to tasquinimod was further investigated by semi-qRT-PCR. TSP1 mRNA induction was dependent both on dose and time. At $10 \mu \mathrm{M}$ tasquinimod the TSP1 mRNA expression was elevated at $6 \mathrm{~h}$ and peaked after $72 \mathrm{~h}$ (Fig. 2A). Moreover, after $72 \mathrm{~h}$ exposure the TSP1 mRNA levels was already elevated at a dose of 1 $\mu \mathrm{M}$ tasquinimod (Fig 2B), indicating that tasquinimodinduced changes in TSP1 mRNA expression occurred in a dose range that has an documented anti-angiogenic and anti-tumor effect in in vivo xenograft models [5]. At higher dose levels (i.e. 50-100 $\mu \mathrm{M}$ ) the mRNA levels declined at $72 \mathrm{~h}$, indicating additional drug effects at these concentrations. The up-regulation of TSP1 mRNA in LNCaP cells by tasquinimod was manifested by an increased expression of TSP1 protein, as shown by western blot analysis of cell lysates prepared from cells cultured for $24 \mathrm{~h}$ and $72 \mathrm{~h}$ (Fig. 3A). Accompanied by increased intracellular TSP1 protein levels was also a statistically significant $(\mathrm{p}<0.05)$ accumulation of extracellular TSP1 in the cell culture medium detected (Fig. 3A (ii)). The extracellular secretion of TSP1 was time dependent 
Table 1: Selected genes differentially expressed in LNCaP prostate tumor cells after exposure to tasquinimod for $24 \mathrm{~h}$.

\begin{tabular}{|c|c|c|c|c|c|}
\hline $\begin{array}{l}\text { Functional groups* } \\
\text { Gene name }\end{array}$ & Accession $\#^{\dagger}$ & Gene $^{\neq}$ & Locus & In vitro & In vivo \\
\hline \multicolumn{6}{|l|}{ Angiogenesis/hypoxia } \\
\hline CD36 antigen (TSP1 receptor) & NM_001001547 & $\mathrm{CD} 36$ & 948 & & + \\
\hline Vascular endothelial growth factor & NM_001025366 & VEGF & 7442 & & - \\
\hline Thrombospondin 1 (THBS1, TSP1) & NM_003246 & THBS1 & 7057 & + & $+* *$ \\
\hline Endothelial PAS domain protein 1 & NM_001430 & EPAS1 & 2034 & & + \\
\hline Neuropilin 2 & NM_003872 & NRP2 & 8828 & & + \\
\hline Stabilin 1 & NM_015136 & STAB1 & 23166 & & + \\
\hline Angiopoietin 2 & NM_001147 & ANGPT2 & 285 & - & - \\
\hline Cadherin 13 & NM_001257 & $\mathrm{CDH} 13$ & 1012 & & + \\
\hline Hypoxia-inducible protein 2 & NM_013332 & HIG2 & 29932 & & - \\
\hline \multicolumn{6}{|l|}{$\begin{array}{l}\text { Cell cycle/differentiation/senescence/ } \\
\text { apoptosis }\end{array}$} \\
\hline Cyclin-depenent inhibitor kinase $1 \mathrm{C}$ & NM_000076 & CDKN1C & 1028 & & - \\
\hline Adrenomedullin & NM_001124 & ADM & 133 & & - \\
\hline Fibroblast growth factor & NM_033136 & FGF1 & 2246 & & + \\
\hline Advanced Glycosylation Endproduct Recept & NM_001136 & AGER & 177 & - & \\
\hline Leukocyte specific transcript protein 1 & NM_007161 & LST1 & 7941 & + & \\
\hline Forkhead box protein N4. & NM_213596 & FOXN4 & 121643 & & + \\
\hline Jun D proto-oncogene; AP-1 complex & NM_005354 & JUND & 3727 & & - \\
\hline \multicolumn{6}{|l|}{ Invasion/migration/adhesion/metastasis } \\
\hline Lysyloxidase preprotein & NM_002317 & LOX & 4015 & - & - \\
\hline Secreted phosphoprotein & NM_00582 & SPP1 & 6996 & - & \\
\hline Chemokine (C-X-C motif) receptor 4 & NM_003467 & CXCR4 & 7852 & & - \\
\hline Spleen tyrosine kinase & NM_003177 & SYK & 6850 & & + \\
\hline Vimentin & NM_003380 & VIM & 7431 & & + \\
\hline CD44 antigen isoform a & NM_000610 & CD44 & 960 & & + \\
\hline CD74 antigen & NM_004355 & CD74 & 972 & & + \\
\hline Insulin-like growth factor binding prot 3 & NM_000598 & IGFBP3 & 3486 & & - \\
\hline S100 calcium-binding protein A6 & NM_014624 & S100A6 & 6277 & & + \\
\hline S100 calcium binding protein $P$ & NM_005980 & S100P & 6286 & & + \\
\hline P8 protein (candidate of metastasis 1 ) & NM_012385 & NUPR1 & 26471 & & - \\
\hline Matrix metalloproteinase 14 & NM_004995 & MMP14 & 4323 & & + \\
\hline Latent transforming GFB-binding prot & NM_032035 & LTBP2 & 4053 & + & \\
\hline Insulin-like growth factor binding prot 7 & NM_001553 & IGFBP7 & 3490 & & + \\
\hline \multicolumn{6}{|l|}{ Stress response/metabolism/DNA repair } \\
\hline cytochrome P450, family 1 , subfamily A & NM_000499 & CYP1A1 & 1543 & + & + \\
\hline cytochrome P450, family 1 , subfamily A & NM_000761 & CYP1A2 & 1544 & + & \\
\hline growth differentiation factor 15 (NAG1) & NM_004864 & GDF15 & 9518 & + & \\
\hline DNA-damage-ind. transcript 3 (GADD153) & NM_004083 & DDIT3 & 1649 & + & - \\
\hline TCDD-inducible poly(ADP-ribose) polymerase & NM_015508 & TIPARP & 25976 & + & + \\
\hline Tumor protein p53 inducible nulear prot 2 & NM_021202 & TP53INP2 & 58476 & + & \\
\hline
\end{tabular}


Table 1: Selected genes differentially expressed in LNCaP prostate tumor cells after exposure to tasquinimod for $\mathbf{2 4} \mathrm{h}$.

\begin{tabular}{|c|c|c|c|c|c|}
\hline \multicolumn{6}{|l|}{ Inflammatory response } \\
\hline Myeloperoxidase & NM_000250 & MPO & 4353 & - & \multirow{4}{*}{-} \\
\hline Interleukin 8 receptor beta & NM_001557 & IL8RB & 3579 & & \\
\hline Interleukin 12 alpha chain & NM_000882 & IL12A & 3592 & - & \\
\hline Serpin peptidase inhibitor 1 & NM_001085 & SERPINA3 & 12 & - & \\
\hline
\end{tabular}

and could clearly be detected after $24 \mathrm{~h}$ exposure to tasquinimod at $10 \mu \mathrm{M}$ (Fig. 3B). Also, TSP1 mRNA levels were induced by tasquinimod at $10 \mu \mathrm{M}$ in the hormone insensitive cell line LNCaP19 but not in DU145 cells (Fig. $3 C)$. The elevated mRNA levels was reflected in a minor increase of intracellular TSP1 protein levels in LNCaP19 cells expressed as a major band of intact protein around $150 \mathrm{kD}$ (Fig. 3D). Taken together, the data obtained from in vitro exposure of human prostate cancer cells to tasquinimod demonstrate a drug effect resulting in increases of both TSP1 mRNA and protein expression.

\section{Up-regulation of TSP1 mRNA and protein levels in vivo in tumor tissue}

Nude mice carrying subcutaneous LNCaP tumors were treated with tasquinimod for 3 weeks. Exposure to tasquinimod at $1 \mathrm{mg} / \mathrm{kg} /$ day and $10 \mathrm{mg} / \mathrm{kg} /$ day started on day 7 after inoculation. There was a statistically significant dose dependent reduction in tumor weight both at 1 $\mathrm{mg} / \mathrm{kg} /$ day and $10 \mathrm{mg} / \mathrm{kg} /$ day compared to the untreated control group 28 days after inoculation $(\mathrm{p}<0.001$, ANOVA; Fig. 4A), illustrating the anti-tumor effect of tasquinimod. The tumor tissue levels of VEGF protein were not increased (Fig. 4B), whereas drug-induced changes in the tumor TSP1 mRNA expression at $10 \mathrm{mg} /$ $\mathrm{kg} /$ day ( $<$ 0.05; Fig. 4C (i)) and in protein levels at 1 and $10 \mathrm{mg} / \mathrm{kg} /$ day were significantly higher after 3 weeks exposure to tasquinimod ( $\mathrm{p}<0.001$, ANOVA; Fig. 4D). The absence of mRNA induction at $1 \mathrm{mg} / \mathrm{kg} /$ day, however, may reflect the difficulty to detect smaller changes in mRNA levels after 3 weeks of continuous exposure at a relatively low dose and that mRNA expression and protein expression not always appear at the same levels in the tissue.

As a control, because the TSP1 antibody (rabbit polyclonal Ab8) cross-reacts with TSP1 of mouse origin, mRNA levels of mouse TSP1 was also measured, to assure that host derived TSP1 was not the source of increased TSP1 production in the treated tumors via infiltrating cells and blood (Fig. 4C(ii)). Immunoflouresence microscopy clearly showed TSP1 protein expression in $\mathrm{LNCaP}$ tumors (Fig. 4E). The most intense labeling was found in regions between zones of tumor growth and peripheral growth regions close to the tumor capsule ("the viable rim"). TSP1 was mainly localized in the extra cellular matrix in relation to blood vessels (Fig. 4E, inset). Thus, the elevated mRNA and protein levels of tumor derived TSP1 in vivo paralleled the observed changes in TSP1 mRNA- and protein expression in vitro.

\section{Tasquinimod blocks the angiogenic switch in CWR-22RH tumors}

The term "angiogenic switch" denotes that in order for cancer to continuously grow, tumors must down-regulate natural angiogenesis inhibitors like TSP1, while coordinately up-regulating angiogenesis stimulators like VEGF [33]. When nude mice bearing CWR-22RH human prostate cancers were treated with oral tasquinimod, there was a profound growth inhibition (Fig. 5A; p $<0.01$ ). Associated with this growth inhibition was a decreased tumor tissue level of VEGF (i.e. a down stream target of HIF1 $\alpha$ ) (Fig. 5B; p < 0.05). Likewise there was a significant up-regulation of TSP1 protein coupled with a down-regulation of HIF1 $\alpha$ protein, androgen receptor protein (AR), and glucose transporter- 1 protein (i.e. down stream target of HIF1 $\alpha$ ) within tasquinimod treated tumor tissues excised and prepared on day 28 (Fig. 5C; p < 0.05). Combined, these data clearly document that tasquinimod has inhibited the "angiogenic switch" within $\mathrm{LNCaP}$ and CWR-2RH xenografts.

\section{Discussion}

In this report we have identified TSP1 as an important player in order to understand and explain the mechanism of the anti-angiogenic, and consequently the anti-tumor effect of tasquinimod treatment of prostate cancer. By using DNA microarray technique to monitor changes in mRNA expression after tasquinimod exposure, in vitro to cultured human LNCaP cells or in vivo to LNCaP tumors grown in nude mice, we were able to identify TSP1 as one potential candidate, among many other differentially expressed genes, for mediating the tasquinimod-induced anti-tumor activity. The increased expression of TSP1 mRNA was further validated by qRT-PCR and on protein 
A.

Mvs. A

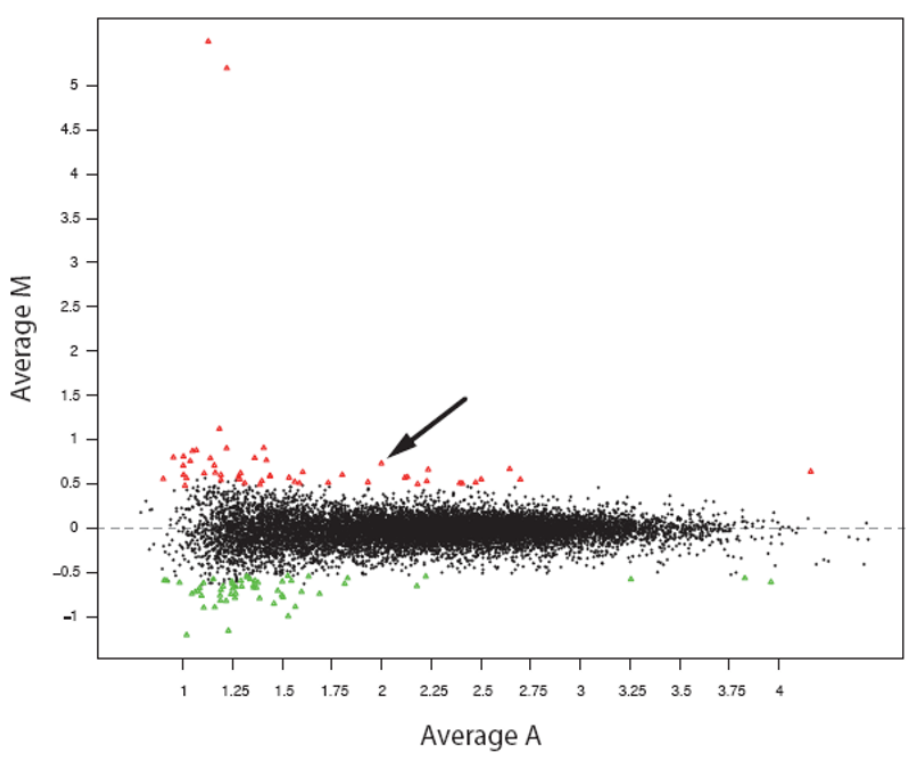

B.

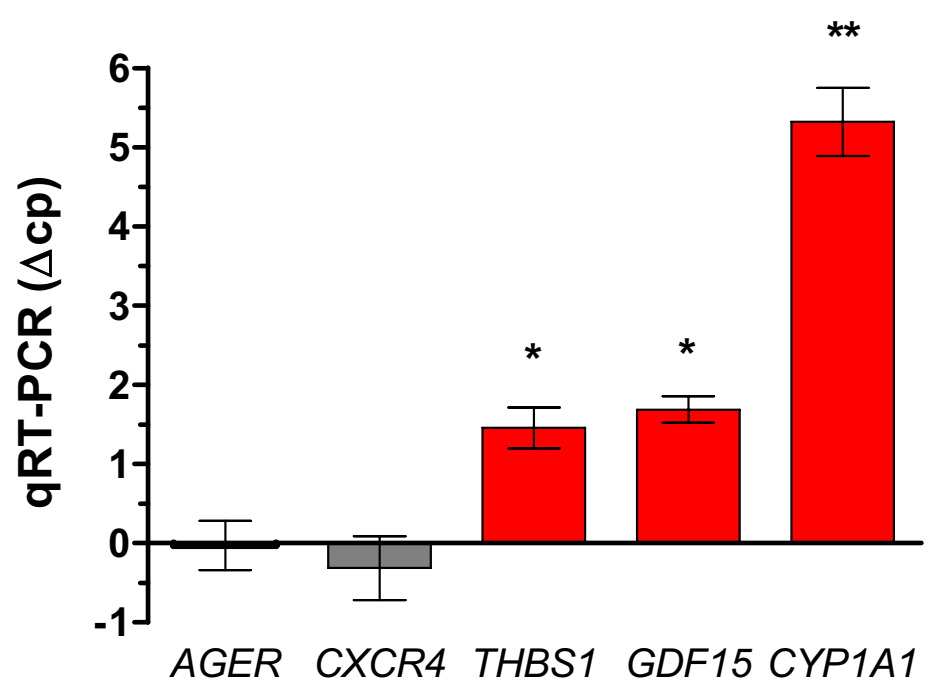

Figure 1 Tasquinimod effects on gene expression in LNCaP cells analyzed with DNA microarray. Altered gene expression induced by tasquinimod in LNCaP cell cultures. (A) Data plot of observed $M\left((M)=\log _{2}(\operatorname{lnt} 1 / \ln t 2)\right)$ versus A (average intensity) from in vitro microarray experiment averaged over biological replicates $(n=4)$. THBS1 (arrow), GDF15 and CYP1A1 were significant outliers in all arrays analyzed (FDR < 10\%; Table 1). (B) Validation of microarray data with semi-gRT-PCR confirmed the up-regulation of THBS, GDF14 and CYP1A1 (red bars; $\triangle \mathrm{cp}$ of 2.32 equals to a 5-fold change in mRNA expression). Expressed data represents the mean \pm SD of at least two independent experiments. $\left(^{*}\right) p \leq 0.05$ and $\left(^{* *}\right) p \leq 0.01$ compared with untreated control (Student's t-test). 
A.

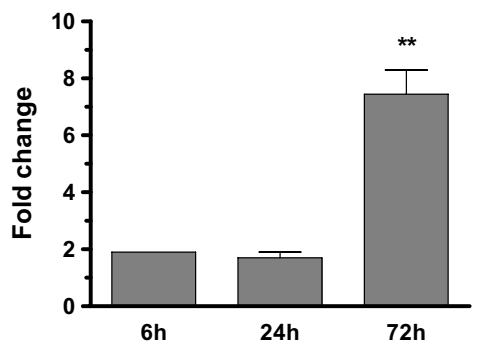

B.

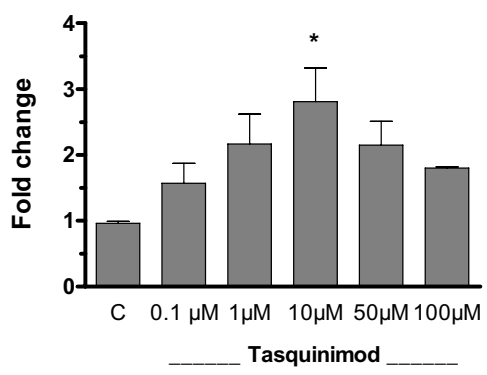

Figure 2 TSP1 mRNA induction by tasquinimod in in vitro tumor cell cultures. Tasquinimod-induced mRNA expression in LNCaP cells measured by real time semi-quantitative RT-PCR. (A) Time study after in vitro exposure with $10 \mu \mathrm{M}$ tasquinimod, and (B) dose response with tasquinimod treatment between $0.1-100 \mu \mathrm{M}$ for $72 \mathrm{~h}(\mathrm{p}=0.0128$, ANOVA). Data expressed represents the mean \pm SD of at least two independent experiments. $\left(^{*}\right) p \leq 0.05$ and $\left(^{* *}\right) p \leq 0.01$ compared with untreated control (Bonferroni's multiple comparison test).

level with western blot and histochemical analysis. Generally, there was a similar gene induction pattern on microarrays from tumor RNA after in vivo exposure. The good agreement between gene induction data achieved by microarray technique and RT-PCR was taken as evidence that the gene induction pattern observed on the microarrays were reliable and reflected an accurate picture of tasquinimod-induced gene expression. Despite the limited numbers of doses and time points, we were able to identify several interesting groups of functional clusters which may be involved in tasquinimods antitumor activity, such as angiogenesis, cell cycle regulation and migration (Table 1).

The nature of tasquinimod-induced increases in mRNA expression measured in tumor tissue after in vivo exposure is probably both of a direct and an indirect character. For example, TSP1, CYP1A1, and GDF15 mRNA induction are most likely reflecting a direct inducing effect on the tumor cells, because elevated mRNA lev- els were also achieved in vitro in cell cultures where no other cell types were present. On the contrary, genes involved in angiogenesis, cell cycle events or cell proliferation may be of an indirect or secondary nature and have a slower kinetic profile. With this in mind, up-regulation of for example the pro-angiogenic FGF1 in the LNCaP tumors were considered of minor importance compared to VEGF since we were not able to measure the FGF levels (by ELISA) in tumors or in cell culture medium from untreated cells or cells treated with tasquinimod (data not shown). TSP1 up-regulation in LNCaP cells involves different pathways including genes such as the PI3K, Akt, PTEN, IGFBP3, $p 21$ (Waf-1) and $p 53$ [19,22], and indeed some of these genes changed expression by tasquinimod exposure in our microarray experiments (Table 1$)$.

In contrast, androgens and the androgen receptor (AR), which is expressed and functional in both $\mathrm{LNCaP}$ and CWR-22RH cells, have been reported to suppress TSP1 expression in tumor cells [34]. Colombel et al. showed that androgen ablation resulted in up-regulation of TSP1 which initially produced an anti-angiogenic response [17]. This therapeutic response was only temporary however, since the cancer cells in the resulting hypoxic environment eventually up-regulated the production of VEGF and thus became completely resistant to the enhanced TSP1 levels. In contrast to this rebound situation following androgen ablation, tasquinimod prevented such up-regulation of VEGF (Figs. 4B and 5B) and thus does not allow the tumor to overcome TSP1 anti-angiogenic effects. This may provide a mechanism that explains why tasquinimod treatment is synergistic when combined with androgen ablation [4]. Our data indicated a gradual difference in TSP1 induction and expression levels between androgen sensitive and refractive tumor cells. There was an evident induction of TSP1 expression at both mRNA and protein levels in the androgen sensitive tumor cells $\mathrm{LNCaP}$ and $\mathrm{CWR}-22 \mathrm{RH}$, whereas there was less induction in LNCaP19, and no measurable induction above constitutive protein levels in the hormone refractive DU145 which lack the androgen receptor completely. Thus, tasquinimod exposure resulting in induction of TSP1 expression may involve effects on the AR and maybe also p53 activity, since cross-talk between these genes has been reported [35]. Besides transcriptional regulation, the anti-angiogenic activity by TSP1 requires proteolysis to liberate soluble anti-angiogenic $\mathrm{N}$ terminal deletion fragments from extra-cellular matrix bound TSP1 and that tumor associated macrophages (TAM's) secrete ADAMTS1, which can perform this TSP1 fragmentation [36]. Once liberated, these soluble TSP1 N-terminal deletion fragments bind VEGF and FGF's in a way that prevents them from stimulating endothelial cells $[37,38]$. Such a process may require 
A.

(i)

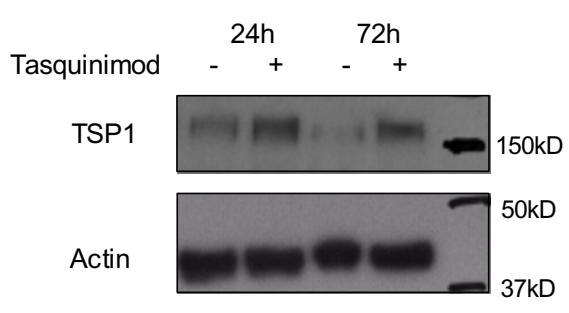

B.

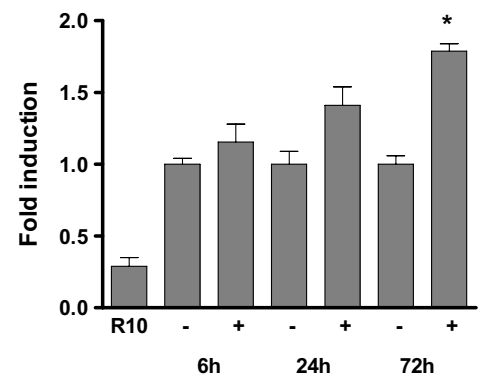

(ii)

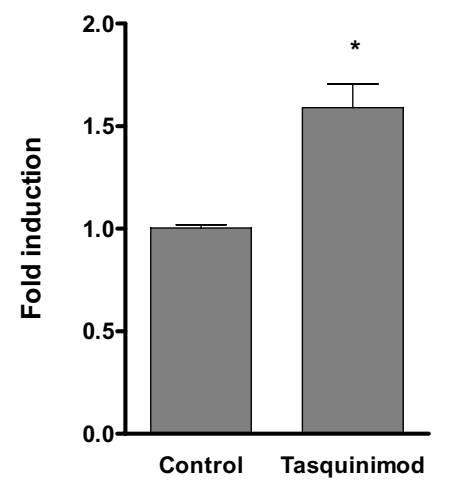

C.

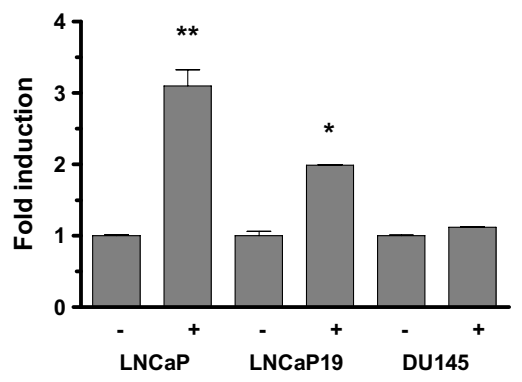

D.

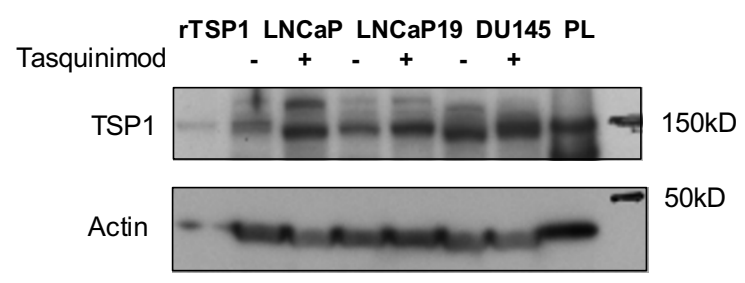

Figure 3 TSP1 expression by LNCaP cells after tasquinimod exposure in in vitro cell cultures. (A) Up-regulation of the TSP1 protein levels by tasquinimod (50 $\mu \mathrm{M}$ ) in LNCaP cells was measured by western blot analysis (left panel (i)). Protein bands represent intact TSP1 at 160 kD (monoclonal Ab1 1). TSP1 secreted into cell culture medium was measured with ELISA after $72 \mathrm{~h}$ (right panel (ii)). The culture medium levels of TSP1 were $50.8 \pm 1.5$ $\mathrm{ng} / \mathrm{ml}$ for untreated cells and $80.6 \pm 10.2 \mathrm{ng} / \mathrm{ml}$ for exposed cells, respectively $(\mathrm{n}=3 ; \mathrm{p} \leq 0.05$, ANOVA). (B) TSP1 secretion into cell culture medium after exposure of LNCaP cells to $10 \mu \mathrm{M}$ tasquinimod (+) ( $p \leq 0.01$, ANOVA). TSP1 levels in untreated (-) cell culture medium were 22, 36.6 and $51.6 \mathrm{ng} /$ $\mathrm{ml}$ after 6,24 and $72 \mathrm{~h}$ incubation, respectively, and $6 \mathrm{ng} / \mathrm{ml}$ in the R10 medium. (C) Up-regulation of TSP1 mRNA levels occurred in the hormone independent prostate cancer cell line LNCaP19 but not in DU145, (-) untreated control and (+) $10 \mu \mathrm{M}$ tasquinimod $(p \leq 0.0001$; ANOVA). Presented data represent the mean \pm SD of at least two independent experiments. $\left(^{*}\right) p \leq 0.05$ and $\left(^{* *}\right) p \leq 0.01$ compared with untreated control (Bonferroni's multiple comparison test). (D) TSP1 protein levels measured by western blot analysis of prostate cancer cell lysates, (-) untreated control and (+) 10 $\mu \mathrm{M}$ tasquinimod for $72 \mathrm{~h}$. PL indicates lysate prepared from human platelets and rTSP1 is recombinant TSP1. 
A.

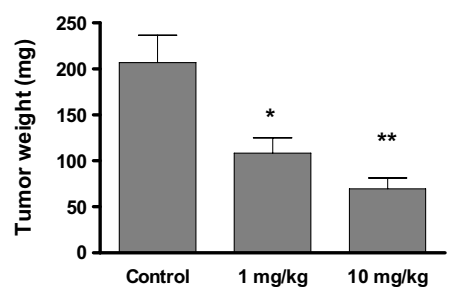

C.

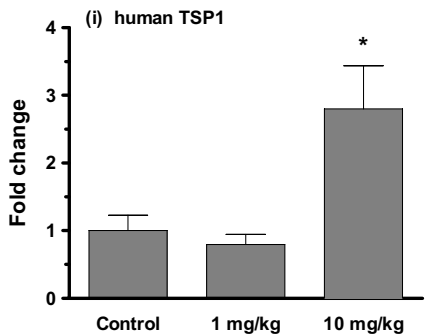

D.
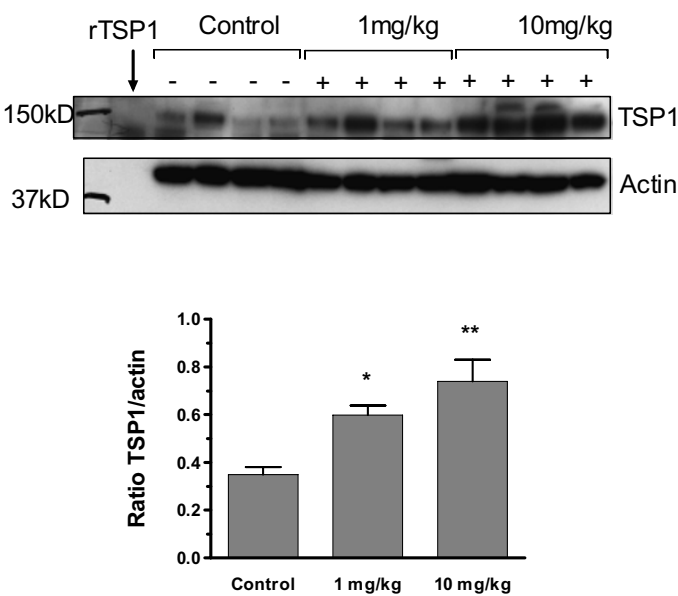

B.
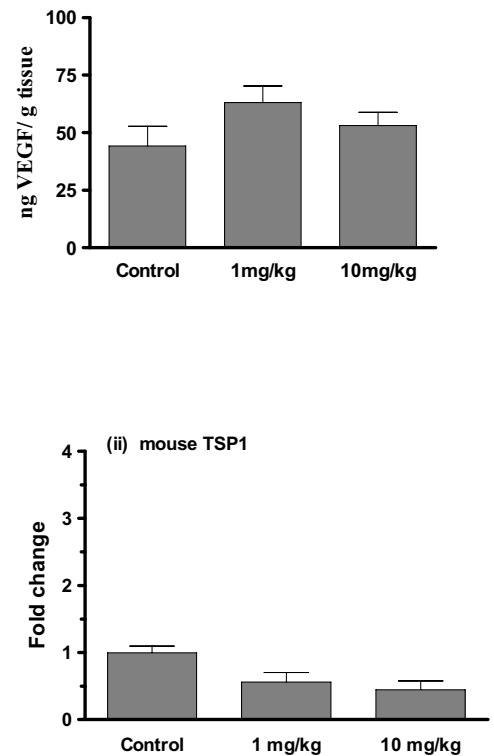

E.

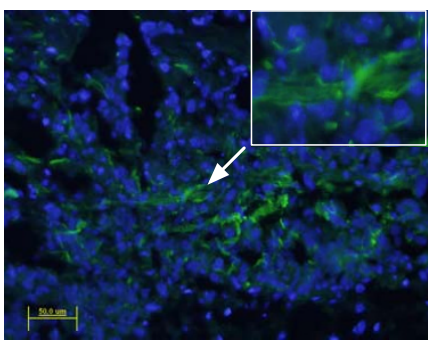

TSP1 (green) / DAPI (blue)

Figure 4 Anti-tumor effect and up-regulation of tumor associated human TSP1 mRNA levels in tasquinimod treated LNCaP tumors. Antitumor effect in nude mice carrying subcutaneous LNCaP tumors treated with tasquinimod ( $10 \mathrm{mg} / \mathrm{kg} / \mathrm{day})$ for three weeks. The treatment started 7 days after inoculation, and expressed data represent the mean tumor weight $\pm S D(n=5 ; p=0.0076, A N O V A)$. (B) VEGF levels were measured in processed tumor tissue by ELISA. (C) Up-regulation, monitored with real-time qRT-PCR, of tumor associated human TSP1 mRNA levels ((i); $p=0.0216$, ANOVA) in LNCaP tumors. To distinguish between mRNA from human tumor cells and infiltrating mouse cells, TSP1 mRNA was analyzed using primers specific for human (i) or mouse (ii) sequences with the same probe set (Table 2). (D) Elevated protein levels of tumor-produced human TSP1 (rabbit polyclonal Ab8). Each lane represents a tumor sample from an individual animal. Calculated ratios between the major band of intact TSP1 (approximately at 150-160 kD) and actin in each lane show a significant $(p=0.0004$, ANOVA) up-regulation of TSP1 tumor levels in exposed animals $((+) ; n=$ 4) compared to untreated controls (-). $\left(^{*}\right) p \leq 0.05$ and $\left(^{* *}\right) p \leq 0.01$ (Bonferroni's multiple comparison test). (E) TSP1 expression (green) analyzed by IHC microscopy in LNCaP tumor tissue exposed in vivo to tasquinimod at $10 \mathrm{mg} / \mathrm{kg} / \mathrm{day}$ (bar $=50 \mu \mathrm{m})$. TSP1 was mainly localized in the extra cellular matrix (inset). Blue shows DAPI staining. 
A.

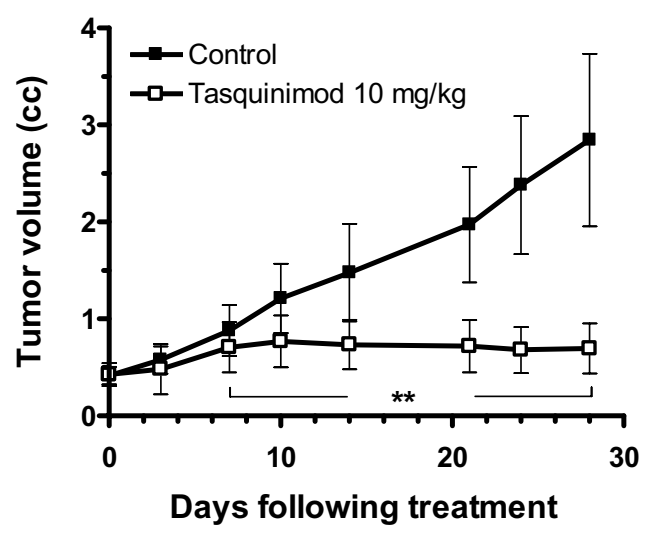

C. (i)

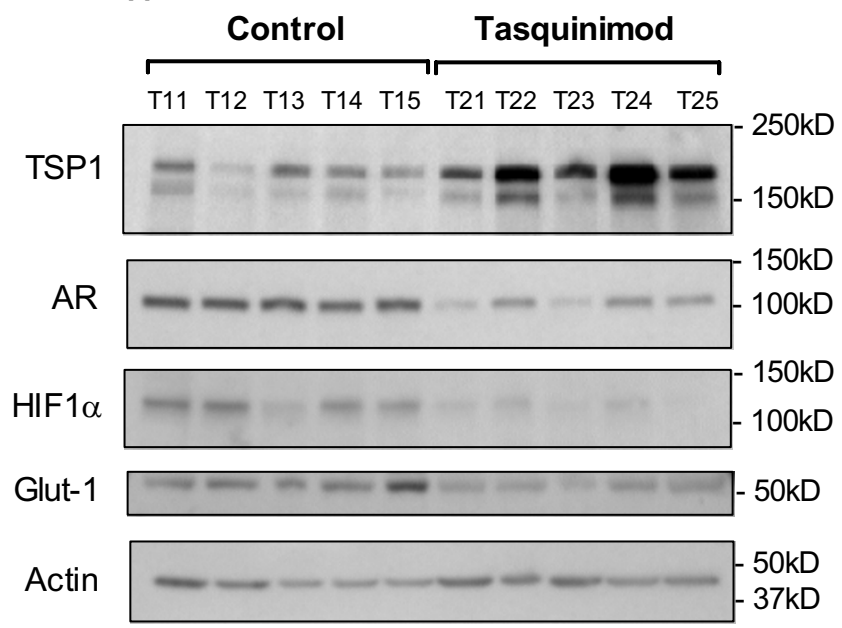

B.

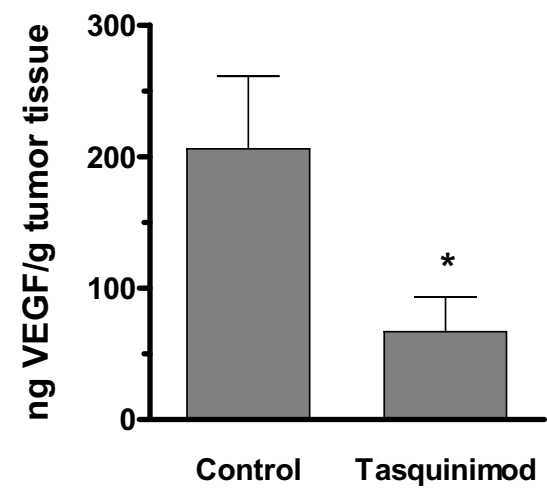

(ii)

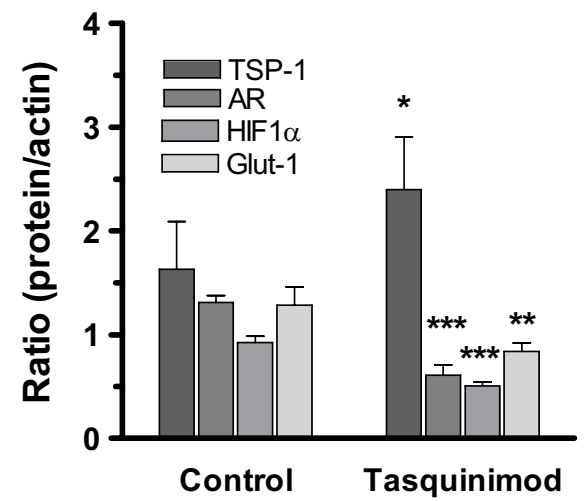

Figure 5 Tasquinimod blocks the angiogenic switch in CWR-22RH tumors. Inhibition of the "angiogenic switch" was illustrated in treated CWR$22 \mathrm{RH}$ tumors. (A) Tumor growth reduction of CWR-22RH human prostate tumors inoculated into nude mice after oral treatment with tasquinimod at $10 \mathrm{mg} / \mathrm{kg} /$ day, data points represent the average $\pm S D,(n=5,(* *) p=0.002 ;$ Mann-Whitney $U)$. (B) Reduced tumor levels of VEGF, a downstream HIF1a target gene. Bars represent the mean $\pm S D, n=5$ and $\left(^{*}\right) p<0.05$. (C) The up-regulation of TSP1 (mouse monoclonal Ab11) in tumor tissue excised and prepared as whole cell lysates (10,000 g supernatant) was accompanied with a down-regulation of the androgen receptor (AR), HIF1a, and Glut1. (i) Each lane represents a tumor sample from an individual animal (\#11 to \#15 controls and \#21 to \#25 exposed to tasquinimod). Molecular weight markers for each blot are indicated. (ii) Calculated ratios between the major protein bands and actin for each lane show a statistical significant difference between exposed animals (\#T21 - \#T25) compared to untreated controls (\#T11-\#T15). $\left(^{*}\right) p \leq 0.05,\left({ }^{* *}\right) p \leq 0.01$ and $\left(^{* *}\right) p \leq 0.001$ (Bonferroni's multiple comparison test).

TAMs to attain tasquinimod's optimal activity in vivo. Recently it was reported that TSP1 modulates VEGF activity at the VEGF receptor level via its TSR interaction and co-clustering with CD36 and $\beta 1$ integrins [39]. The documented anti-angiogenic and anti-tumor of up-regu- lated TSP1 in prostate cancers does however not always be the case for other types of cancers [40], indicating a dual effect of TSP1 on angiogenesis and tumor progression (reviewed by [41]). 
The mode of action behind of the quinoline compounds anti-tumor properties has not been fully resolved, but several studies have shown that this group of compounds effect tumor angiogenesis [4,5], macrophage infiltration [42], cytokine production [43], and autoimmune/inflammatory disease [44]. Hence, the immunomodularly properties of the quinolines indicate existence of an immunological component as a key player in quinoline compounds mode of action resulting in anti-tumor activity. This component is likely to be TAMs, and recently Martin-Manso et al. [26] reported that tumorproduced TSP1 promoted the recruitment of M1-polarized TAMs which stimulated reactive oxygen species (ROS)-mediated cytotoxicity of the endothelial cells and thereby caused inhibition of angiogenesis and tumor progression. By facilitating the infiltration of TAMs with a M1-phenotype (expressing high levels of iNOS and high production of NO) over TAMs of the proangiogenic M2phenotype, it may be that tasquinimod-induced tumor levels of TSP1 change the balance between M1 and M2 cells. Thus, changes in such a critical ratio of NO to ROS generation would be able to destabilize the HIF $1 \alpha$ protein even under hypoxic conditions [45]. This may explain tasquinimod's ability to provide an anti-angiogenic milieu by down-regulate HIF1 $\alpha$ protein levels and its down stream targets, VEGF and Glut-1 proteins in human xenografts as they grow in nude mice (Fig. 5B \&5C). Interesting, "M2-like" tumor infiltrating myeloid-derived suppressor cells (MDSCs) is a cell population with a phenotype similar to M2 macrophages expressing high levels of arginase1 [46] and S100A9 protein [47]. The calcium and zink dependent protein S100A9 regulates the accumulation of tumor infiltrating MDSCs [48], and tasquinimod as a representative of quinoline compounds which recently were described as a strong binders to S100A9 [44], may have inhibited the MDSC accumulation and thereby prohibited MDSCs/M2 macrophages to act in a pro-angiogenic and pro-tumor fashion. Thus, the involvement of an additional mechanism could be possible, meaning that tasquinimod may act in LNCaP tumors both by inducing TSP1 production and TAM (M1) recruitment and at the same time inhibit the accumulation of MDSCs and prevent M2 macrophage action via direct interference with the S100A9 protein in immature myeloid cells. This possibility will be the subject of future studies of the mechanism of action of tasquinimod.

\section{Conclusions}

We conclude that tasquinimod-induced up-regulation of TSP1 is part of a mechanism involving down-regulation of HIF $1 \alpha$ and VEGF, which in turn leads to reduced angiogenesis via inhibition of the "angiogenic switch", that could explain tasquinimod's therapeutic potential

\section{Materials and methods Cell culture and materials}

Tasquinimod was synthesized at Active Biotech Research AB (Lund, Sweden), as previously described [49]. In this study tasquinimod was used in vitro at doses between $0.1-100 \mu \mathrm{M}$ and at 1 and $10 \mathrm{mg} / \mathrm{kg} / \mathrm{day}$ in vivo, based upon pharmacokinetic studies [5] where daily oral dosing with $1-30 \mathrm{mg} / \mathrm{kg} /$ day produced serum levels of tasquinimod in the $1-4 \mu \mathrm{M}$ range. Two human prostate cancer cell lines, CWR-22RH and LNCaP (ATCC) are both androgen independent, but remain sensitive to androgen stimulation of growth, express PSA and a mutated androgen receptor [4]. The hormone independent cell lines LNCaP19 [50] and DU145 were also tested for TSP1 induction after in vitro exposure to tasquinimod. CWR22RH, LNCaP and DU145 were grown in RPMI Medium 1640 containing 10\% FCS and L-Glutamine mixture, while LNCAP19 was cultured in RPMI-medium with 10\% hormone free (RDCC) FCS.

\section{Animals}

Nude BALB/c mice were used for subcutaneous implantation of human prostate tumor cells LNCaP and CWR22RH [4]. All animal experiments were conducted in accordance with the Bioethics Committee guidelines in Lund, Sweden. Tumor growth was measured with a microcaliper twice a week throughout the experiment, and the final tumor burden was measured by weight on the day of termination of the experiment. Distribution of tasquinimod at $1 \mathrm{mg} / \mathrm{kg} /$ day and $10 \mathrm{mg} / \mathrm{kg} /$ day (administered orally via the drinking water) started on day 7 after inoculation.

\section{RNA preparation}

Tissue samples in vitro or in vivo were collected and stored at $-70^{\circ} \mathrm{C}$ in Trizol $^{\circ}$ (Invitrogen). The total RNA was isolated by extracting the Trizol samples with chloroform followed by separation and purification using a modified protocol for the RNeasy RNA extraction Kit (Qiagen). 1 $\mu l$ RNAse inhibitor mix was added per $50 \mu$ l total RNA before treatment with DNAse for 20 min (DNA-free ${ }^{\mathrm{mw}}$; Ambion, Austin TX). The RNA concentration and purity was quality controlled by analysis with a Bioanalyser.

\section{Microarray experiments}

LNCaP cells were exposed in vitro to $50 \mu \mathrm{M}$ tasquinimod for $24 \mathrm{~h}$ before harvest and RNA extraction. Tumor bearing mice ( $\mathrm{LNCaP}$ inoculated in nude mice) were treated with tasquinimod at $10 \mathrm{mg} / \mathrm{kg}$ (ad.lib.) and the tumors of each of the 2 different treatment groups were excised after $24 \mathrm{~h}$ of treatment (start day 14 or day 21 after inoculation) and total RNA was isolated. Untreated samples were grown and harvested in parallel and used as controls for microarray experiments. The RNA from treated and 
control samples were differentially labeled with fluorescent dye (Cy3 \& Cy5) and hybridized on human oligoarrays as described [51]. All hybridizations were replicated using dye-swap for the flourecent dyes, and data from image-analysis were loaded into a local installation of BioArray Software Environment (BASE) [52] for preprocessing and normalization. Spots from dye-swap hybridization were merged using geometric mean of ratios requiring presence in both replicates. For spots, log ratio $(\mathrm{M})$ was calculated as $\log _{2}(\mathrm{Int} 1 / \mathrm{Int} 2)(\mathrm{Int} 1=$ treated sample intensity and Int $2=$ control intensity) and average intensity (A) was calculated as $\log _{10}($ Int1*Int2)/2. Normalization was performed by applying Lowess on $\mathrm{M}$ values stratified into 8 separate groups defined spatially by pin-tip (8 neighboring pin-tips per group). Probe replicates were merged and a probe presence in 3 of 4 biological replicates was required for inclusion in further analysis. All microarray data will be made available in NCBI's Gene Expression Omnibus (GEO) accessible through GEO Series entry GSE17031.

\section{Real-time semi-quantitative Reversed Transcriptase-PCR (semi-qRT-PCR)}

Total RNA was reversed transcribed using the "Transcriptor First Strand cDNA Synthesis Kit" (Roche) and anchored oligo- $(\mathrm{dT})_{18}$ primers. PCR primers and fluorogenic probes (with an $640 \mathrm{tag}$ ) for the human "housekeeping" gene hGAPDH and the five genes to validate, THBS1, CXCR4, CYP1A1, GDF15 and AGER were designed, synthesized and purified by TIB MOLBIOL (Berlin, Germany) (Table 2). Real Time PCR was performed using the "LightCycler FastStart DNAMasterplus Hybidization Probes" kit (Roche). Cycling parameters were as follows: Denaturation step for $10 \mathrm{~min}$ at $94^{\circ} \mathrm{C} / /$ Amplification step (40-50 cycles) was $10 \mathrm{~s}$ at $95^{\circ} \mathrm{C} \_10 \mathrm{~s}$ at $56^{\circ} \mathrm{C}_{-} 20 \mathrm{~s}$ at $72^{\circ} \mathrm{C} / / 30 \mathrm{~s}$ at $33^{\circ} \mathrm{C}$, the transition rate was $20^{\circ} \mathrm{C} / \mathrm{s}$ for all steps except for $72^{\circ} \mathrm{C}$ to $90^{\circ} \mathrm{C}$ which was $10^{\circ} \mathrm{C} / \mathrm{s}$. To measure up- or down-regulation of cellular mRNA levels, CP-values (i.e. GAPDH - tested gene) were calculated from at least three different analysis using varied cDNA concentrations.

\section{Western blotting}

SDS-/PAGE and western blot analysis was performed on the $10,000 \mathrm{~g}$ supernatant fraction of total soluble proteins prepared from cell pellets or from frozen tumor tissue $(100 \mu \mathrm{g})$. Briefly, frozen tumor tissue was weighed and diced into small pieces. Ice cold lysis buffer $(20 \mathrm{mM}$ Tris $\mathrm{HCl} \mathrm{pH} 7.4$ with $150 \mathrm{mM} \mathrm{NaCl}, 1 \mathrm{mM}$ EDTA, $0.5 \%$ NP40) $0.5 \%$ sodium deoxycholate, $1 \mathrm{mM}$ DTT, protease inhibitor cocktail (Roche), $1.5 \mathrm{mM}$ sodium vanadate, 1 $\mu \mathrm{M}$ cystine and $80 \mathrm{mM}$ sodium glycerophosphate) was added, homogenized, and centrifuged at 10,000 g for 15 minutes. $10 \mu \mathrm{g}$ protein was loaded in each lane on a 4-
$12 \%$ Bis-Tris gel, the protein transferred to a PVDF transfer membrane (Immobilon-P, Millipore), and blocked overnight in $5 \%$ dry fat-free milk in TBST. Incubation with anti-hTSP1 Ab11 (clones D4.6 + A6.1 + MBC200.1) or Ab8 (rabbit polyclonal; Lab Vision, NeoMarkers CA, USA) was performed using mouse anti-human-actin as an internal control (Sigma). Both antibodies showed cross-reactivity to mouse derived TSP 1 and the detection patterns were similar for both antibodies (i.e. Ab8 and Ab11). Recombinant human TSP1 protein (140 kD, ProSpec-Tany TechnoGene LTD, Israel) was loaded at 3 ng and anti-bodies against androgen receptor (AR; rabbit polyclonal, (N-20) Santa Cruz), HIF1 $\alpha$ (mouse monoclonal from BD) and Glut1 (rabbit polyclonal, (H-43) Santa Cruz) were all used at 1:500 dilution.

As secondary detection antibodies, (HRP)-conjugated anti-rabbit antibody or anti-mouse antibodies (Amersham) were used, followed by detection with the chemoluminiscence ECL-Plus reagent (Amersham, UK), developed on ECL Hyperfilm (GE Healthcare, UK), captured and analyzed using a Kodak Digital Science ${ }^{\mathrm{nt}}$ Image Station 440F.

\section{Elisa measurements}

VEGF content in tumor tissue and TSP1 levels in cell culture medium were measured by ELISA (VEGF, Biosurce, Belgium; \#KHG0112, and TSP1, Quantikine R\&D Systems Europe Ltd, UK; \#DTSP10) according to the manufacturer's protocol.

\section{Immuno histoflouresence (IHF) microscopy}

Tumor tissue, were fixed in 4\% paraformaldehyde (PBS), immersed in $15 \%$ and $25 \%$ sucrose/PBS, tissues were mounted in Tissue-Tek (Sakura Finetek Europe, Netherland) and immediately frozen on carbon dioxide ice. Cryosections were cut $(10 \mu \mathrm{m})$ and two sections were collected per slide, comprising at least two levels of the tumor. General tissue morphology was visualized by hematoxylin and eosin staining. For immunohisto-fluorescence (IHF) labeling of frozen tissue sections was the anti-human TSP1 antibody (Ab8).IHF labeling was accompanied by nuclear staining with DAPI (Molecular Probes, USA).

\section{Statistical analysis}

For microarray experiments, genes were selected for upor down-regulated transcript expression after exposure to tasquinimod compared to non-exposed controls. Using independent biological replicates the probability of observed mean $M$ was calculated for each reporter using a BASE plug-in implementation of one-class Z-test [52] with the null hypothesis that the reporter is non-differentially expressed. The null distribution was derived from pooled standard deviation and mean for the biological 
Table 2: Primer and probe sets used for RT-PCR and semi-quantitative real time PCR*.

\begin{tabular}{|c|c|c|c|}
\hline Target gene & $\begin{array}{l}\text { Primer } \\
\text { Sequence }\left(5^{\prime}=>3^{\prime}\right)\end{array}$ & $\begin{array}{l}\text { Probe }^{\dagger} \\
\text { Sequence }\left(5^{\prime}=>3^{\prime}\right)\end{array}$ & $\begin{array}{l}\text { Amplicon } \\
\text { length (bp) }\end{array}$ \\
\hline hu GAPDH & $\begin{array}{l}\text { FW: gAAggTgAAggTCggAgTC } \\
\text { Rev: gAAgATggTgATgggATTC }\end{array}$ & $\begin{array}{l}\text { AggggTCATTgATggCAACAATATCCA-FL } \\
\text { LC:640-TTACCAgAgTTAAAAgCAgCCCTggTg }\end{array}$ & 226 \\
\hline hu TSP-1 & $\begin{array}{l}\text { FW: CTggACTCgCTgTAggTTA } \\
\text { Rev: CCCTgTggTggAgTTAC }\end{array}$ & $\begin{array}{l}\text { AgTCATCgTCCCTTCggTg-FL } \\
\text { LC: } 640-T g A T g A A g A A g g T g C C A C T g A A g T\end{array}$ & 233 \\
\hline hu CXCR4 & $\begin{array}{l}\text { FW: CgAggAAATgggCTCAg } \\
\text { Rev: gggAAgCgTgATgACAAA }\end{array}$ & $\begin{array}{l}\text { ПTाTATTgAAATTAgCATTाTCTTCACggA-FL } \\
\text { LC:640-ACAggg TTCCTTCATggAgTCATAgTCC }\end{array}$ & 273 \\
\hline hu CYP1A1 & $\begin{array}{l}\text { FW: gAgCTgggTTTgACACAgTC } \\
\text { Rev: ggATgTAAAAgCCTTTCAAACT }\end{array}$ & $\begin{array}{l}\text { gTCggAAggTCTCCAggATgAAg-FL } \\
\text { LC: } 640-C C T C C A T A T A g g g C A g A T g g g A T C T g\end{array}$ & 258 \\
\hline hu GDF15 & $\begin{array}{l}\text { FW:gAAgACTCCAgATTCCgAgAgTT } \\
\text { Rev:gATCCCAgCCgCACTTCT }\end{array}$ & $\begin{array}{l}\text { gATTCgAACACCgACCTCgTCCC-FL } \\
\text { LC: } 640-\text {-gCCCCTgCAgTCCggATACTCAC }\end{array}$ & 146 \\
\hline hu AGER & $\begin{array}{l}\text { FW: TCTgCCTCTgAACTCACgg } \\
\text { Rev: CCTTCACAgATACTCCCTTCTCATT }\end{array}$ & $\begin{array}{l}\text { CAgggACTCTTAgCTggCACTTgg--FL } \\
\text { LC: } 640-\text { TgggAAAgCCCCTggTgCCT }\end{array}$ & 139 \\
\hline huTSP-1 ${ }^{\ddagger}$ & $\begin{array}{l}\text { FW: AACggAgTTCAgTACAgAAAT } \\
\text { Rev: TTCCATTgCCACAgCTC }\end{array}$ & $\begin{array}{l}\text { CAgAACTCRgTTACCATCTgCAAAAAgg-FL } \\
\text { LC: } 640-\text {-gTCCTgYCCCATCATgCCCTgC }\end{array}$ & 235 \\
\hline$m T s p-1^{\ddagger}$ & $\begin{array}{l}\text { FW: AgAgAACAgAgAgCTggTCAg } \\
\text { Rev: ATCTgTTgTgAggCTgTCA }\end{array}$ & & 329 \\
\hline mPbgd & $\begin{array}{l}\text { FW:TTgTACCCTggCATACAgTTTgA } \\
\text { Rev: gTTCCCACggCACTTTC }\end{array}$ & $\begin{array}{l}\text { TgAAggATgTgCCTACCATACTACCTCCT-FL } \\
\text { LC: } 640-g C T T \text { ACTATTggAgCCATCTgCAAAC }\end{array}$ & 247 \\
\hline
\end{tabular}

replicates. Obtained probabilities $(\mathrm{P})$ were used to rank reporters and to calculate expected number of reporters (expected) for each rank. False discovery rate (FDR) was estimated by comparing the expected number of reporters and rank, i.e., expected/rank. To select differentially expressed reporters a cut-off was set at false discovery rate $10 \%(\mathrm{FDR}<0.10)[52]$.

The statistical significance of difference between experimental conditions was determined using One-way ANOVA analysis ( $\mathrm{p} \leq 0.05$ based on $\mathrm{F}$ values) with twotailed Student's t-test with Bonferroni's correction for comparison of multiple groups, $(*) \mathrm{p} \leq 0.05$ and $(* *) \mathrm{p} \leq$ 0.01 .

\section{Additional material}

Additional file 1 Table S1 - Genes up- and down regulated at FDR $<$ $0.1(10 \%)$ after in vitro exposure to Tasquinimod for $24 \mathrm{~h}$. The indicated column headings (bold) are explained as follows (also indicated as foot notes): (+) indicates up-regulation in treated vs untreated and (-) indicates down-regulation in treated versus untreated*, Absolute fold change between untreated and treated cellst, Average $\mathbf{M}$ of biological replicates $\neq$, $\mathbf{n}=$ number of biological replicates ${ }^{* *}, \mathbf{P}=$ probability of obtaining the observed average $\mathrm{M}$ (Z-test) $\mathbf{\dagger +}, \mathbf{R a n k}=$ ranked genes based on obtained probabilities (i.e., the reporter with lowest $P$ will have rank 1 ) $\neq \neq$, Expected $=$ expected number of reporters calculated as probability times total number of reporters ***, and FDR $=$ number of expected number of reporters divided by observed number of reporters (rank) 
Additional file 2 Table S2 - Genes up- or down-regulated at FDR $<0.1$ (10\%) after in vivo exposure to Tasquinimod for $24 \mathrm{~h}$ at $10 \mathrm{mg} / \mathrm{kg}$. The indicated column headings (bold) are explained as follows (also indicated as foot notes): (+) indicates up-regulation in treated vs untreated and (-) indicates down-regulation in treated versus untreated*, Absolute fold change between untreated and treated cellst, Average $\mathbf{M}$ of biological replicates $\mathbf{n} \mathbf{n}=$ number of biological replicates ${ }^{* *}, \mathbf{P}=$ probability of obtaining the observed average $M$ (Z-test) $\mathbf{\dagger}+$, Rank = ranked genes based on

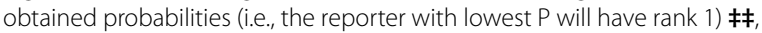
Expected $=$ expected number of reporters calculated as probability times total number of reporters ${ }^{* * *}$, and $\mathbf{F D R}=$ number of expected number of reporters divided by observed number of reporters (rank) $\neq \neq \neq$.

\section{Competing interests}

$A O, A B$ and $T L$ are employees of Active Biotech $A B$ that is a company developing quinolines for commercial purposes. JVC and JTI declare that they have no competing interests.

\section{Authors' contributions}

$\mathrm{AO}, \mathrm{AB}$ and $\mathrm{TL}$ initiated and planned the project. $\mathrm{AO}$ performed the experimental design, analyzed the microarray data, performed pathway analyses, designed primers, carried out QPCR, ELISA and western blots, drafted and wrote the manuscript. TL participated in the set up of the initial study, the experimental design, carried out the overall responsibility of the research performed and revised the manuscript critically. JVC planned, processed and analyzed the microarray data, performed statistical analyses, contributed to the writing of the manuscript and made the microarray data available in NCBI's Gene Expression Omnibus. JTI planned, performed and analyzed all the experiments associated with the CWR-22RH tumor model and changes in the angiogenic switch. All authors read and approved the final manuscript.

\section{Acknowledgements}

These studies were supported by a sponsored research agreement between Active Biotech Research and The Johns Hopkins University School of Medicine. Financial support were provided by the Swedish Cancer Foundation (TL), the Swedish Research Council (TL) and the American Cancer Society (JVC). The authors would like to acknowledge the use of SCIBLU Genomics at Lund University. The authors gratefully acknowledge Örjan Nodle for statistical consultation, Dr. Marie Törngren and Madeleine Jacobson-Andén at Active Biotech Research, and Dr. Bo Holmqvist at ImaGene-iT, University of Lund, for performing the fluorescence- and immuno histochemistry.

\section{Author Details}

${ }^{1}$ Active Biotech AB, Box 724, 22007 Lund, Sweden, 2Department of Oncology, Clinical Sciences, and CREATE Health Strategic Center for Translational Cancer Research, Lund University, Lund, Sweden, ${ }^{3}$ The Sidney Kimmel Comprehensive Cancer Center, The Johns Hopkins University School of Medicine, Baltimore Maryland, USA and ${ }^{4}$ Immunology Group, BMC D14, Lund University, 22184 Lund, Sweden

Received: 24 September 2009 Accepted: 17 May 2010

Published: 17 May 2010

\section{References}

1. Folkman J, Merler E, Abernathy C, Williams G: Isolation of a tumor factor responsible for angiogenesis. J Exp Med 1971, 133:275-288.

2. Hanahan D, Folkman J: Patterns and emerging mechanisms of the angiogenic switch during tumorigenesis. Cell 1996, 86:353-364.

3. Bratt O, Haggman M, Ahlgren G, Nordle O, Bjork A, Damber JE: Openlabel, clinical phase I studies of tasquinimod in patients with castration-resistant prostate cancer. Br J Cancer 2009, 101(8):1233-40.

4. Dalrymple SL, Becker RE, Isaacs JT: The quinoline-3-carboxamide antiangiogenic agent, tasquinimod, enhances the anti-prostate cancer efficacy of androgen ablation and taxotere without effecting serum PSA directly in human xenografts. Prostate 2007, 67:790-797.

5. Isaacs JT, Pili R, Qian DZ, Dalrymple SL, Garrison JB, Kyprianou N, Bjork A, Olsson A, Leanderson T: Identification of ABR-215050 as lead second generation quinoline-3-carboxamide anti-angiogenic agent for the treatment of prostate cancer. Prostate 2006, 66:1768-1778.
6. Kazerounian S, Yee KO, Lawler J: Thrombospondins in cancer. Cell Mol Life Sci 2008, 65:700-712.

7. Ren B, Yee KO, Lawler J, Khosravi-Far R: Regulation of tumor angiogenesis by thrombospondin-1. Biochim Biophys Acta 2006 1765:178-188.

8. Armstrong LC, Bjorkblom B, Hankenson KD, Siadak AW, Stiles CE, Bornstein $P$ : Thrombospondin 2 inhibits microvascular endothelial cell proliferation by a caspase-independent mechanism. Mol Biol Cell 2002, 13:1893-1905.

9. Lawler J, Detmar M: Tumor progression: the effects of thrombospondin1 and -2. Int J Biochem Cell Biol 2004, 36:1038-1045.

10. Jimenez B, Volpert OV, Crawford SE, Febbraio M, Silverstein RL, Bouck N: Signals leading to apoptosis-dependent inhibition of neovascularization by thrombospondin-1. Nat Med 2000, 6:41-48.

11. Nor JE, Mitra RS, Sutorik MM, Mooney DJ, Castle VP, Polverini PJ: Thrombospondin-1 induces endothelial cell apoptosis and inhibits angiogenesis by activating the caspase death pathway. J Vasc Res 2000, 37:209-218.

12. Isenberg JS, Ridnour LA, Dimitry J, Frazier WA, Wink DA, Roberts DD: CD47 is necessary for inhibition of nitric oxide-stimulated vascular cell responses by thrombospondin-1. J Biol Chem 2006, 281:26069-26080.

13. Isenberg JS, Yu C, Roberts DD: Differential effects of ABT-510 and a CD36-binding peptide derived from the type 1 repeats of thrombospondin- 1 on fatty acid uptake, nitric oxide signaling, and caspase activation in vascular cells. Biochem Pharmacol 2008, 75:875-882.

14. Doll JA, Reiher FK, Crawford SE, Pins MR, Campbell SC, Bouck NP: Thrombospondin-1, vascular endothelial growth factor and fibroblast growth factor- 2 are key functional regulators of angiogenesis in the prostate. Prostate 2001, 49:293-305.

15. Rodriguez-Manzaneque JC, Lane TF, Ortega MA, Hynes RO, Lawler J, Iruela-Arispe ML: Thrombospondin-1 suppresses spontaneous tumor growth and inhibits activation of matrix metalloproteinase- 9 and mobilization of vascular endothelial growth factor. Proc Natl Acad Sci USA 2001, 98:12485-12490.

16. Campbell SC, Volpert OV, Ivanovich M, Bouck NP: Molecular mediators of angiogenesis in bladder cancer. Cancer Res 1998, 58:1298-1304.

17. Colombel M, Filleur S, Fournier P, Merle C, Guglielmi J, Courtin A Degeorges A, Serre CM, Bouvier R, Clezardin P, Cabon F: Androgens repress the expression of the angiogenesis inhibitor thrombospondin1 in normal and neoplastic prostate. Cancer Res 2005, 65:300-308.

18. Watnick RS, Cheng YN, Rangarajan A, Ince TA, Weinberg RA: Ras modulates Myc activity to repress thrombospondin-1 expression and increase tumor angiogenesis. Cancer Cell 2003, 3:219-231.

19. Su JD, Mayo LD, Donner DB, Durden DL: PTEN and phosphatidylinositol 3'-kinase inhibitors up-regulate p53 and block tumor-induced angiogenesis: evidence for an effect on the tumor and endothelial compartment. Cancer Res 2003, 63:3585-3592.

20. Goel HLML, Murphy-Ullrich JE, Hsieh CC, Wu CL, Jiang Z, Languino LR: Beta1 integrin cytoplasmic variants differentially regulate expression of the antiangiogenic extracellular matrix protein thrombospondin 1. Cancer Research 2009, 69:5374-5382.

21. Kang JH, Kim MJ, Chang SY, Sim SS, Kim MS, Jo YH: CCAAT box is required for the induction of human thrombospondin-1 gene by trichostatin A. J Cell Biochem 2008, 104:1192-1203.

22. Wen S, Stolarov J, Myers MP, Su JD, Wigler MH, Tonks NK, Durden DL: PTEN controls tumor-induced angiogenesis. Proc Natl Acad Sci USA 2001, 98:4622-4627

23. Maloney SL, Sullivan DC, Suchting S, Herbert JM, Rabai EM, Nagy Z, Barker J, Sundar S, Bicknell R: Induction of thrombospondin-1 partially mediates the anti-angiogenic activity of dexrazoxane. Br J Cancer 2009, 101:957-966.

24. Yamauchi Y, Kuroki M, Imakiire T, Abe H, Uchida H, Beppu R, Yamashita Y, Shirakusa T: Thrombospondin-1 differentially regulates release of IL-6 and IL-10 by human monocytic cell line U937. Biochem Biophys Res Commun 2002, 290:1551-1557.

25. Bornstein P: Thrombospondins as matricellular modulators of cell function. J Clin Invest 2001, 107:929-934.

26. Martin-Manso G, Galli S, Ridnour LA, Tsokos M, Wink DA, Roberts DD: Thrombospondin 1 promotes tumor macrophage recruitment and enhances tumor cell cytotoxicity of differentiated U937 cells. Cancer Res 2008, 68:7090-7099. 
27. Ridnour LA, Isenberg JS, Espey MG, Thomas DD, Roberts DD, Wink DA: Nitric oxide regulates angiogenesis through a functional switch involving thrombospondin-1. Proc Natl Acad Sci USA 2005, 102:13147-13152

28. Damber JE, Vallbo C, Albertsson P, Lennernas B, Norrby K: The antitumour effect of low-dose continuous chemotherapy may partly be mediated by thrombospondin. Cancer Chemother Pharmacol 2006 58:354-360

29. Miao WM, Seng WL, Duquette M, Lawler P, Laus C, Lawler J: Thrombospondin-1 type 1 repeat recombinant proteins inhibit tumor growth through transforming growth factor-beta-dependent and independent mechanisms. Cancer Res 2001, 61:7830-7839.

30. Haviv F, Bradley MF, Kalvin DM, Schneider AJ, Davidson DJ, Majest SM, McKay LM, Haskell CJ, Bell RL, Nguyen B, Marsh KC, Surber BW, Uchic JT, Ferrero J, Wang YC, Leal J, Record RD, Hodde J, Badylak SF, Lesniewski RR, Henkin J: Thrombospondin-1 mimetic peptide inhibitors of angiogenesis and tumor growth: design, synthesis, and optimization of pharmacokinetics and biological activities. J Med Chem 2005, 48:2838-2846

31. Dennis G Jr, Sherman BT, Hosack DA, Yang J, Gao W, Lane HC, Lempicki RA: DAVID: Database for Annotation, Visualization, and Integrated Discovery. Genome Biol 2003, 4:P3.

32. Hosack DA, Dennis G Jr, Sherman BT, Lane HC, Lempicki RA: Identifying biological themes within lists of genes with EASE. Genome Biol 2003, 4:R70.

33. Bergers $G$, Benjamin LE: Tumorigenesis and the angiogenic switch. Nat Rev Cancer 2003, 3:401-410.

34. Johnson AM, O'Connell MJ, Miyamoto H, Huang J, Yao JL, Messing EM, Reeder JE: Androgenic dependence of exophytic tumor growth in a transgenic mouse model of bladder cancer: a role for thrombospondin-1. BMC Urol 2008, 8:7.

35. Shenk JL, Fisher CJ, Chen SY, Zhou XF, Tillman K, Shemshedini L: p53 represses androgen-induced transactivation of prostate-specific antigen by disrupting hAR amino- to carboxyl-terminal interaction. $J$ Biol Chem 2001, 276:38472-38479.

36. Lee NV, Sato M, Annis DS, Loo JA, Wu L, Mosher DF, Iruela-Arispe ML: ADAMTS1 mediates the release of antiangiogenic polypeptides from TSP1 and 2. EMBO J 2006, 25:5270-5283.

37. Margosio B, Marchetti D, Vergani V, Giavazzi R, Rusnati M, Presta M, Taraboletti G: Thrombospondin 1 as a scavenger for matrix-associated fibroblast growth factor 2. Blood 2003, 102:4399-4406.

38. Margosio BRM, Bonezzi K, Cordes BL, Annis DS, Urbinati C, Giavazzi R, Presta M, Ribatti D, Mosher DF, Taraboletti G: Fibroblast growth factor-2 binding to the thrombospondin-1 type III repeats, a novel antiangiogenic domain. Int J Biochem Cell Biol 2008, 40:700-709.

39. Zhang $X$ : Thrombospondin-1 modulates vascular endothelial growth factor activity at the receptor level. FASEB J 2009, 23(10):3368-3376.

40. Tuszynski GP, Gasic TB, Rothman VL, Knudsen KA, Gasic GJ: Thrombospondin, a potentiator of tumor cell metastasis. Cancer Res 1987, 47:4130-4133.

41. Morandi $\mathrm{V}$ : The N-Terminal Domain of Thrombospondin-1: a key for the Dual Effect of TSP-1 in Angiogenesis and Cancer Progression? The ScientificWorld Journal 2009, 9:133-136.

42. Vukanovic J, Hartley-Asp B, Isaacs JT: Inhibition of tumor angiogenesis and the therapeutic ability of linomide against rat prostatic cancers. Prostate 1995, 26:235-246.

43. Diab A, Michael L, Wahren B, Deng GM, Bjork J, Hedlund G, Zhu J: Linomide suppresses acute experimental autoimmune encephalomyelitis in Lewis rats by counter-acting the imbalance of pro-inflammatory versus anti-inflammatory cytokines. J Neuroimmunol 1998, 85:146-154.

44. Björk P, Björk A, Vogl T, Stenström M, Liberg D, Olsson A, Roth J, Ivars F, Leanderson T: Identification of human S100A9 as a novel target for treatment of autoimmune disease via their binding to quinoline carboxamides. PLoS biology 2009, 7:e97.

45. Kohl R, Zhou J, Brune B: Reactive oxygen species attenuate nitric-oxidemediated hypoxia-inducible factor-1alpha stabilization. Free Radic Biol Med 2006, 40:1430-1442.

46. Umemura N, Saio M, Suwa T, Kitoh Y, Bai J, Nonaka K, Ouyang GF, Okada M, Balazs M, Adany R, Shibata T, Takami T: Tumor-infiltrating myeloidderived suppressor cells are pleiotropic-inflamed monocytes/ macrophages that bear M1- and M2-type characteristics. J Leukoc Biol 2008, 83:1136-1144.

47. Cheng P, Corzo CA, Luetteke N, Yu B, Nagaraj S, Bui MM, Ortiz M, Nacken W, Sorg C, Vogl T, Roth J, Gabrilovich DI: Inhibition of dendritic cell differentiation and accumulation of myeloid-derived suppressor cells in cancer is regulated by S100A9 protein. J Exp Med 2008, 205:2235-2249.

48. Sinha P, Okoro C, Foell D, Freeze HH, Ostrand-Rosenberg S, Srikrishna G: Proinflammatory s100 proteins regulate the accumulation of myeloidderived suppressor cells. J Immunol 2008, 181:4666-4675.

49. Jonsson S, Andersson G, Fex T, Fristedt T, Hedlund G, Jansson K, Abramo L, Fritzson I, Pekarski O, Runstrom A, Sandin H, Thuvesson I, Björk A: Synthesis and biological evaluation of new 1,2-dihydro-4-hydroxy-2oxo-3-quinolinecarboxamides for treatment of autoimmune disorders: structure-activity relationship. J Med Chem 2004, 47:2075-2088.

50. Gustavsson H, Welen K, Damber JE: Transition of an androgendependent human prostate cancer cell line into an androgenindependent subline is associated with increased angiogenesis. Prostate 2005, 62:364-373.

51. Jonsson G, Staaf J, Olsson E, Heidenblad M, Vallon-Christersson J, Osoegawa K, de Jong P, Oredsson S, Ringner M, Hoglund M, Borg A: Highresolution genomic profiles of breast cancer cell lines assessed by tiling BAC array comparative genomic hybridization. Genes Chromosomes Cancer 2007, 46:543-558.

52. Saal LH, Troein C, Vallon-Christersson J, Gruvberger S, Borg A, Peterson C: BioArray Software Environment (BASE): a platform for comprehensive management and analysis of microarray data. Genome Biol 2002, 3:SOFTWARE0003.

doi: 10.1186/1476-4598-9-107

Cite this article as: Olsson et al., Tasquinimod (ABR-215050), a quinoline-3carboxamide anti-angiogenic agent, modulates the expression of thrombospondin-1 in human prostate tumors Molecular Cancer 2010, 9:107

\section{Submit your next manuscript to BioMed Central and take full advantage of:}

- Convenient online submission

- Thorough peer review

- No space constraints or color figure charges

- Immediate publication on acceptance

- Inclusion in PubMed, CAS, Scopus and Google Scholar

- Research which is freely available for redistribution

Submit your manuscript at www.biomedcentral.com/submit
C BioMed Central 